\title{
Audit Firm Size, Audit Fee, Audit Reputation and Audit Quality: The Case of Listed Companies in Vietnam
}

\author{
Ngoc Kim Pham, Hung Nguyen Duong, \& Tin Pham Quang \\ University of Economics, Danang University
}

Nga Ho Thi Thuy

Hue University College of Economics, Vietnam

Received: Sep. 26, 2016 Accepted: June 29, $2017 \quad$ Published: June 29, 2017

doi:10.5296/ajfa.v9i1.10074 URL: http://dx.doi.org/10.5296/ajfa.v9i1.10074

\begin{abstract}
Audit quality is considered as an essential factor affecting the reliability of financial information. The aim of this study is to assess the effects of audit firm characteristics, including audit reputation, audit fees and audit firm size, on audit quality. A sample of 192 companies listed on Hanoi and Ho Chi Minh Stock Exchange for the period of 2006-2014 was selected. Multiple regression was used to analyze the data. The findings show that Big 4 auditors in Vietnam provide high audit quality than non-Big 4 auditors. Interestingly, in Vietnam context, except for the audit firms in the Big 4 group, the findings suggest that smaller audit firms provide better audit quality. Additionally, the results reveal that the more audit fees the auditors receive, the lower audit quality they provide. The critical role of audit quality has attracted significantly scholarly attention, however, prior studies have mainly focused on firms in developed countries. Little is known about audit quality in an emerging economy context such as Vietnam. This study adds to the limited number of studies on audit quality of listed companies in emerging economies.
\end{abstract}

Keywords: Audit quality, Audit reputation, Audit firm size, Audit fees, Proxies of audit quality. 


\section{Introduction}

The agency conflicts between managers and principals (e.g. shareholders and creditors) may affect the quality of reported information. Managers may provide financial information dishonestly to protect their own interests while the principals cannot directly observe managers' behavior (Ramadan, 2015; Williams, 1988). External audits help to reduce information asymmetries between managers and principals by lending credibility to financial statements (Almomani, 2015; Carey, 2008). Thus, audit quality needs to be high to ensure their client firms to disclose better quality of information in a timelier manner to protect principals.

The critical role of audit quality has attracted significantly scholarly attention. However, prior studies have mainly focused on firms in developed countries (Beisland et al., 2015). This is the first study to examine the relationship between audit firm characteristics and audit quality from firms operating in a an emerging economy - Vietnam. Emerging economies, especially Vietnam, still exists a big gap between entities and their providers of capital because their corporate-governance mechanisms are still evolving (Mamun and Badir, 2014). It is also because the legal systems in emerging economies are not sufficient enough to protect investors' rights as such in developed countries (Pham and Hoang, 2015). Recent studies (Ha, 2014; Pham and Hoang, 2015) indicated that the findings of the audit quality in the developed economies may not necessary apply in emerging economies.

Audit quality is a major concern for young independent audit sector in Vietnam. Independent audit industry in Vietnam was formed in 1991 with only two audit firms. This number increased to 134 firms with the average number of employees being 78 people in 2014 (Bùi Văn Mai, 2014). Although the number of independent audit firms in Vietnam grew rapidly, they still do not meet the demand of external audit services of firms operating in Vietnam (Vu, 2010). Further, the collapse of a number of public companies in Vietnam, such as Bach Tuyet Corporation and Far East Pharmaceutical JSC raises series of problems posed for the fraudulent financial information of these public companies and the audit quality of audit firms in Vietnam (Oxford Analytica, 2008).

Although audit quality is very important for Vietnam, research on this issue is still limited. Only a few studies (e.g. Pham et al., 2014) have investigated the audit quality of listed companies in Vietnam. Pham et al. (2014) examined the relationships between audit engagement, non-audit services, auditor's expertises and audit quality. This study did not investigate the associations between audit firms characteristics and audit quality. Therefore, understanding the associations between audit firm characteristics and audit quality in Vietnam is still a significant gap in the literature. This study addressed this gap by examining the relationship between audit firm size, audit reputation and audit fees, and audit quality.

This paper is structured as follows. The paper begins with a literature review on audit quality. This is followed by hypotheses development. Research methods and the results of this study are also presented. The paper concludes with discussion of the results, limitations and suggestions for future research. 


\section{Literature review}

\subsection{Audit quality}

Several studies provided definitions of audit quality with diverse ideas. These definitions can be classified into two approaches, namely: 1) the probability that auditors detect and report misstatements, and 2) the level compliance with auditing standards (DeFond and Zhang, 2014; Tritscher, 2013), which will be discussed next.

Following the first approach, researcher defines audit quality based on the quality of financial statements (Tritscher, 2013). DeAngelo (1981) defined audit quality as 'the market-assessed joint probability that given an auditor will both discover a breach in the client's accounting system, and report the breach' (p.186). Audit quality depends on both the probability that auditors detect misstatements and on whether auditors report such misstatements (DeAngelo, 1981; Palmrose, 1988). Low audit quality occurs when audited financial reports contain misstatements that are not detected and reported by the auditor. Thus, audit quality is associated with the quality of audited financial reports as higher audit quality provides greater assurance of high financial reporting quality (DeFond and Zhang, 2014).

With regard to the second approach, DeFond and Zhang (2014) suggested that auditors have responsibilities to comply with generally accepted auditing standards to ensure high audit quality. Carcello (2002) also argued that audit quality is associated with the level of compliance with auditing standards. Thus, audit quality is measured by the differences between the required level of assurance and the actual level of assurance achieved by audit procedure (Carcello et al., 2002).

Due to the lack of the method to directly assess audit quality, researchers (e.g. Grenier et al., 2007) focused on defining "poor audit quality" by identifying adverse outcomes from an audit, such as audit failures. It is easy to operationalize the definition of audit quality in terms of audit failures as the failures can be observable (Augustine et al., 2014). For example, poor audit quality can be measured when a litigation claim against the audit firm (Casterella et al., 2009). However, it is difficult to measure audit quality since relatively few cases of audit failures have been detected (Francis, 2011).

In Vietnam, in particular, audit quality has not been specifically and clearly defined in any existing studies. Directly measuring and assessing audit quality, hence, are complicated since audit quality cannot be observed explicitly. Moreover, the factors contributing to audit procedure in order to create the final result of the audit report, are not published by audit firms. Lacking such information makes it difficult for users to assess audit quality directly. This consequently triggers the critical need of Vietnamese audit firms as well as the authority to create a framework for assessing and managing audit operation appropriately.

\subsection{Proxy to measure audit quality}

Due to different views on defining audit quality, the measurements of audit quality have yet not been reached a general acceptance. However, proxies to measure audit quality can be classified into three categories: 1) going-concern opinions, 2) material misstatements and 3) 
earnings management, which will be discussed in the following sections.

2.2.1 Going-concern opinions. As for going-concern opinions approach, researchers (Francis, 2011; Lennox, 1999) measure audit quality by relying on the relationship between going-concern audit reports and client business failures. Incorrect going-concern opinions are appropriate indicators for low audit quality (Francis, 2011; Lennox, 1999). Low audit quality happens when a going-concern opinion is not issued before client failures (Francis, 2011). Following this approach, audit firms have high audit quality when a going-concern opinion is an appropriate indicator of client' failures (Francis, 2011).

However, using going-concern opinions as a proxy to measure audit quality is challenging, because the business failures of clients can be consequences of unforeseen business situations in the future (Tritscher, 2013). It may be related to business forecasting rather than analyzing facts obtained from historical financial reporting (Tritscher, 2013). Further, going-concern opinions can contribute to a client' business failures when banks and suppliers refuse credits to this client (Tritscher, 2013). In addition, inappropriate going-concern opinions only contribute a small portion of low audit quality as many types of material misstatements are not related to a going-concern opinion (Tritscher, 2013). Therefore, whether going-concern opinions is an appropriate measure of audit quality depends on each cases (Tritscher, 2013).

2.2.2 Material misstatements. The two most commonly used misstatement measures in prior studies includes restatements and Accounting and Auditing Enforcement Releases (AAERs) (DeFond and Zhang, 2014). Accounting restatements refer to the corrections of material misstatements in the client's previously issued financial statements (Alyousef and Almutairi, 2010). Restatements and AAERs are actually direct measures of audit quality because they indicate that the auditor issued an unqualified opinion on materially misstated financial statements, and the audit opinion is the auditor's full responsibility and directly under his or her control (DeFond and Zhang, 2014).

Empirical studies (e.g. Raghunandan et al., 2003) show that there is an implicit relationship between financial statement restatements and low audit quality. For instance, Raghunandan, Read, and Whisenant (2003) asserted that their examination of the relationship between non-audit fees and subsequent restatements indicates a direct relationship between non-audit fees and audit quality. Palmrose and Scholz (2000) studied auditor litigation resulting from restatements which are at the intersection of financial reporting quality and audit quality. Further, misstatements arise from not adequately identifying of high-risk accounts and transactions by the auditors (Palmrose and Scholz, 2000). Restatements in their sample identified accounting issues such as revenue recognition could have been identified by the auditors as high risk in their audit planning and performance.

However, financial restatements and AAERs are not always good indicators of poor audit quality (DeFond, 2010; Tritscher, 2013). Firms normally merit their financial statements when poor earning quality is detected and judged by the firms (DeFond, 2010). Thus, financial restatements and AAERs may not capture unintentional or undetected errors (DeFond, 2010). Further, financial restatements may be due to changes in accounting policies, therefore, they are not results of audit failures (Tritscher, 2013). 


\section{Macrothink}

2.2.3 Earnings management. There are different definitions of earnings management in the literature (Ronen and Yaari, 2008). According to Ronen and Yaari (2008), prior studies follow at least two approaches to define earnings management, namely: (1) earnings management is choosing accounting treatment to enhance the transparency of reports or (2) to maximize the utility of management. Given these different approaches, Healy and Wahlen's (1999) definition is the best description of earnings management in the literature (Ronen and Yaari, 2008). Healy and Wahlen (1999) stated that "earnings management occurs when managers use judgment in financial reporting and in structuring transactions to alter financial reports to either mislead some stakeholders about the underlying economic performance of the company or to influence contractual outcomes that depend on reported accounting numbers" (p. 368).

However, it is difficult to observe earnings management directly, thus, most prior studies use discretionary or abnormal accruals as proxies for earnings management (Tritscher, 2013). The discretionary accruals measurement of Jones (1991) is the most influential model which is represented in equation (1) and (2). The equation (1) is used to measure discretionary accruals which are equal total accruals minus non-discretionary accruals. Total accruals are calculated from net profit minus net cash flow.

$D A_{t}=T A_{t}-N D A_{t}$

$$
=\left(N P_{t}-N C F_{t}\right)-\left(\beta_{1}\left(1 / A_{t-1}\right)+\beta_{2}\left(\triangle R E V_{t} / A_{t-1}\right)+\beta_{3}\left(P P E_{t} / A_{t-1}\right)\right)
$$

Where

$\mathrm{DA}_{\mathrm{t}} \quad$ Discretionary accruals in year $\mathrm{t}$

$\mathrm{TA}_{\mathrm{t}} \quad$ Total accruals in year $\mathrm{t}$

$\mathrm{NDA}_{t} \quad$ Non-discretionary accruals in year $\mathrm{t}$

$\mathrm{NP}_{\mathrm{t}} \quad$ Net Profit in year $\mathrm{t}$

$\mathrm{NCF}_{\mathrm{t}} \quad$ Net Cash Flow in year $\mathrm{t}$

$\triangle \mathrm{REV}_{\mathrm{t}} \quad$ Revenues in year $\mathrm{t}$ less revenues in year $\mathrm{t}-1$

PPE $_{t} \quad$ Gross property plant and equipment at the end of year $t$

$A_{t \_1} \quad$ Total assets at the end of year $t-1$

$\beta_{1}, \beta_{2}, \beta$ Estimated firm-specific parameters by using the model in equation (3)

$$
T A_{t} / A_{t-1}=\alpha_{1}\left(1 / A_{t-1}\right)+\alpha_{2}\left(\left(\triangle R E V_{t} / A_{t-1}\right)+\alpha_{3}\left(P P E / A_{t-1}\right)+\varepsilon_{t}\right.
$$

Where

$\alpha_{1}, \alpha_{2}, \alpha_{3} \quad$ Denote the OLS estimatesof $\beta_{1}, \beta_{2}, \beta_{3}$

$\varepsilon_{\mathrm{t}} \quad$ Residual (the firm-specific discretionary portion of total accruals)

Earnings management (discretionary/abnormal accruals) is an appropriate measure to 
evaluate audit quality as audited financial statements are working outcomes of both managers and auditors (DeFond and Zhang, 2014; Sundgren and Svanström, 2013). Indeed, abnormal portion of accruals is initiated by managers in order to control earnings that benefit for themselves rather than other financial users (Tritscher, 2013). Managers tends to choose accounting treatment for managing earnings in order to get higher bonus from their firms' earnings (Becker et al., 1998; Schipper, 1989), to satisfy the debt covenants (Becker et al., 1998) or to reduce political costs (Jones, 1991). Auditors may not detect earnings management due to their limited resources or may not report earnings management since audit comfort is highest when the audit risk is lowest (Tritscher, 2013). In another word, earnings management is eliminated by high audit quality, thus, it is an appropriate proxy of audit quality (DeFond and Zhang, 2014). Table I summarizes strengths and weaknesses of the proxies for audit quality.

Table I. Audit quality proxy measurement comparative

\begin{tabular}{|c|c|c|}
\hline $\begin{array}{c}\text { Proxy } \\
\text { Category }\end{array}$ & Strengths & Weaknesses \\
\hline $\begin{array}{l}\text { Material } \\
\text { misstatements }\end{array}$ & $\begin{array}{l}\checkmark \text { Strong evidence of poor audit } \\
\quad \text { quality }\end{array}$ & $\begin{array}{l}\checkmark \text { Does not capture subtle quality } \\
\text { variation } \\
\checkmark \text { Cannot infer high quality from } \\
\text { lack of misstatements }\end{array}$ \\
\hline $\begin{array}{l}\text { Going concern } \\
\text { opinions }\end{array}$ & $\begin{array}{l}\checkmark \text { Strong evidence of poor audit } \\
\quad \text { quality } \\
\checkmark \text { Uniquely captures auditor } \\
\quad \text { independence }\end{array}$ & $\begin{array}{l}\checkmark \text { Does not capture subtle quality } \\
\text { variation } \\
\checkmark \text { Only applies to distressed firms, } \\
\quad \text { limits generalizability }\end{array}$ \\
\hline \multirow[t]{3}{*}{$\begin{array}{l}\text { Earning } \\
\text { quality (EQ) }\end{array}$} & $\begin{array}{l}\checkmark \text { Tightly linked to concept of } \\
\text { audit quality }\end{array}$ & $\begin{array}{l}\checkmark \text { Results of the measurement } \\
\text { depend on previous data }\end{array}$ \\
\hline & $\begin{array}{l}\checkmark \text { Evidence of within Generally } \\
\text { accepted accounting } \\
\text { principles manipulation } \\
\checkmark \text { May signal more egregious } \\
\text { undetected misstatements } \\
\checkmark \text { Captures quality variation for }\end{array}$ & $\begin{array}{l}\checkmark \text { Some case, materiality of } \\
\text { classification and disclosure on } \\
\text { the financial statement not } \\
\text { include on the earning quality. } \\
\text { There for no exactly when using } \\
\text { the EQ is proxy for audit quality }\end{array}$ \\
\hline & & $\begin{array}{l}\checkmark \text { Limited consensus on } \\
\text { measurement } \\
\checkmark \text { Potentially large measurement } \\
\text { errors }\end{array}$ \\
\hline
\end{tabular}

Source: DeFond \& Zhang (2014) 
In Vietnam, data about errors and weaknesses of audit firms in the investigation of appropriate authorities is not available (Bùi Văn Mai, 2014). The quantity of audit firms that are under suspicion about their audit service quality does not represent all audit firms in Vietnam. Further, the portion of going-concern opinions of auditors is extremely low; hence, this cannot be used to reflect audit quality. Correspondingly, this study uses earnings management measurement (discretionary accruals) as a proxy for the quality of auditing Vietnamese listed companies' financial statements.

\subsection{Studies of audit quality in emerging economies}

There are few research on audit quality in the emerging economies context, which showed indicated that the findings of the audit quality in the developed economies may not necessary apply in emerging economies (Beisland et al., 2015; Ha, 2014; Pham and Hoang, 2015). Because firms operated in emerging economies have different legal systems and corporate governances from that of firms located in developed one. The following paragraphs will critically synthesis previous studies on audit quality in emerging economies to highlight the above differences and the need for additional research on audit quality in an emerging economy, such as Vietnam.

Beisland et al. (2015) examined the relationships between audit quality (measured by Big 4 auditors) and corporate governances of microfinance institutions from 73 emerging or developing economies. The results of the study showed that there are no or weak correlations between audit quality and corporate-governance factors. The findings of the study provide evidences that microfinance institions in emerging/developing economies are different from those in developed economies in terms of auditor choice when they appoint auditors with fundamental economic forces rather than devoting much attention to corporate governance.

Competition

\subsection{Vietnam context}

This research was conducted in an emerging economy context, Vietnam, for three main reasons. First, Vietnam had young stock exchanges which are associated with many issues related to the transparency of both financial and non-financial information (Quang, 2013). Information disclosures of listed companies in Vietnam are more perfunctory in nature and are not detailed (International Finance Corporation, 2011). Most Vietnam listed companies do not report regularly or in details the management information so that it is hard to analyze and evaluate the actual business activities of these companies in a timely manner (Do and Ngo, 2015).

Second, most of Vietnam listed companies have poor corporate governance (International Finance Corporation, 2012; Quang, 2013). Board of directors is decentralized with great power (Do and Ngo, 2015), whereas shareholders and audit committees do not undertake their full rights (Vietnam Investment Review, 2015). The weakness area of corporate governance of Vietnam listed companies is the effectiveness of the shareholders' rights when these companies less adhere shareholders' rights (International Finance Corporation, 2012). 
The decentralization of power to executive board lead to financial frauds that help protect the interest of executive board while detriment that of shareholders (Do and Ngo, 2015).

Third, auditor independence is an another issue. According to the law of Vietnam (Vietnamese Government Office, 2002), audit committees have to oversight the activities of external auditors. In fact, external auditors normally work with the board of directors. Further, shareholders normally empower their rights to appoint external auditors and negotiate with auditors to the board of directors. Meanwhile, the disclosure of auditor independence and audit activities are rare in either annual general meeting or other company documents (International Finance Corporation, 2012). Thus, the close relationship between auditors and board of directors, and the dislosure in Vietnam listed companies may impair auditor independence (International Finance Corporation, 2012).

Although there are few of studies on audit quality have conducted in other emerging economies, the results were still mixed. With the three key institutional factors of Vietnam, the finding of the studies in other emerging economies may not apply for the Vietnam context. Therefore, there is still a significant gap in the literature to understand the audit quality in Vietnam listed companies.

\section{Hypotheses development}

\subsection{Audit firm reputation and audit quality}

Audit firm reputation relates to the corporate image which comes over time (Aronmwan et al., 2013). It may be a consequence of the array of auditors, the firm possesses, the brand name, the perceived audit quality and the fees charged (Aronmwan et al., 2013). Reputation is also a result of audit firms' technical and functional quality (Sucher et al., 1999).

Audit firms can be broadly classified into two groups: Big 4 auditors as a reputable group and non-Big 4 auditors as a non-reputable group (Boulila Taktak and Mbarki, 2014; DeAngelo, 1981). Big 4 auditors are argued to provide better quality audits than non-Big 4 auditors (Boulila Taktak and Mbarki, 2014; Klein and Leffler, 1981). This is because reputable firms (e.g. Big 4 auditors) want to sustain their reputation and fear losing what they have built if they provide low quality services (Bigus, 2015; Klein and Leffler, 1981). Extreme audit failures can damage audit firms' reputation and these firms may lose all of their customers (DeFond and Zhang, 2014). Reputable audit firms also have high quality auditing because they normally have higher income from their assurance services and have higher power to maintain their recognized qualifications (Aronmwan et al., 2013). With a higher financial resource, reputable audit firms also have higher motivation to spend on training and hiring competent auditors to protect their reputation (Rezaei and Shabani, 2014). Reputable audit firms have motivations to provide better assurance services to maintain their reputation, which, in turn, lead to higher price premium that these firms can receive from their clients (Choi et al., 2010; Desai et al., 2016).

Further, reputable audit firms normally have higher motivation to reduce errors and mistakes than non-reputable partners (Beatty, 1989; Bigus, 2015). Thus, reputable audit firms have high audit quality as they can ensure their clients disclose better quality of information 
(Aronmwan et al., 2013). Thus, higher earnings response coefficient was also found in clients audited by Big 4 firms compared to those audited by non-Big 4 firms (Teoh and Wong, 1993). Big 4 auditors are better at constraining client earnings management than non-Big 4 auditors, with evidence showing that clients of non-Big 4 auditors have higher levels of discretionary accruals or lower audit quality (Becker et al., 1998; Francis and Wang, 2008; Krishnan, 2003). Thus, the following hypothesis is proposed:

H1. Audit firm reputation is positively related to audit quality.

\subsection{Audit firm size and audit quality}

Several studies (e.g. DeAngelo, 1981; Lawrence et al., 2011; Rezaei and Shabani, 2014) have supported that larger audit firms provide higher quality-audit services than smaller ones. This is because larger auditors are less likely to depend on their particular clients' economic (Rezaei and Shabani, 2014). Thus, they are less likely to agree with their client pressure for reporting misstatements than small audit firms (Choi et al., 2010). Further, they have higher motivation to deliver high-quality services in order to protect their brand name reputation (Rezaei and Shabani, 2014) as larger audit firms may have greater reputation losses in case of audit failures than small firms (DeAngelo, 1981). Further, big audit firms have higher technical competence and greater resources (Lawrence et al., 2010). They also have more experienced and competent auditors and greater expertise than small audit firms (Francis and Yu, 2009). Francis, Maydew and Sparks (1999), however, argued that high audit quality in larger audit firms may be not because of their excellent auditor's performance but mainly because of the large client effect (Francis et al., 1999). Given different perspectives on explaining the effect of the audit firm size on audit quality, several empirical studies have provided evidences supporting that the bigger audit firm size is positively associated with higher audit quality. Hence, the study proposes the next hypothesis as follows:

H2. Audit firm size is positively related to audit quality.

\subsection{Audit fees and audit quality}

The fees paid to auditors may influence audit quality (Simunic, 1980). The positive association between audit fees and proxies for audit quality has been supported in prior studies (e.g. Ettredge et al., 2014; Hoitash et al., 2007; Simunic, 1980). For example, Hoitash et al. (2007) found that the total audit and non-audit fees are negatively related to both proxies to measure audit quality (the standard deviation of residuals from regressions relating current accruals to cash flows and the absolute value of performance-adjusted discretionary accruals). Ettredge et al. (2014) supported that audit fee pressure during the economic downturn is positively related to accounting misstatements.

There are some explanations for the positive relationships between audit fees and audit quality. Choi et al. (2010) indicated that audit firms that provide high-quality audit services charge higher audit fees than those offer low-quality services as costs to deliver high audit quality are higher than that of low-quality auditing. High fees may encourage auditors to increase their efforts, which in turn, positively affects audit quality (Hoitash et al., 2007; Wooten, 2003). Hence, the following hypothesis is proposed: 
H3. Audit fees are positively related to audit quality.

Figure I shows the conceptual model of factors related to audit firm characteristics affecting audit quality.

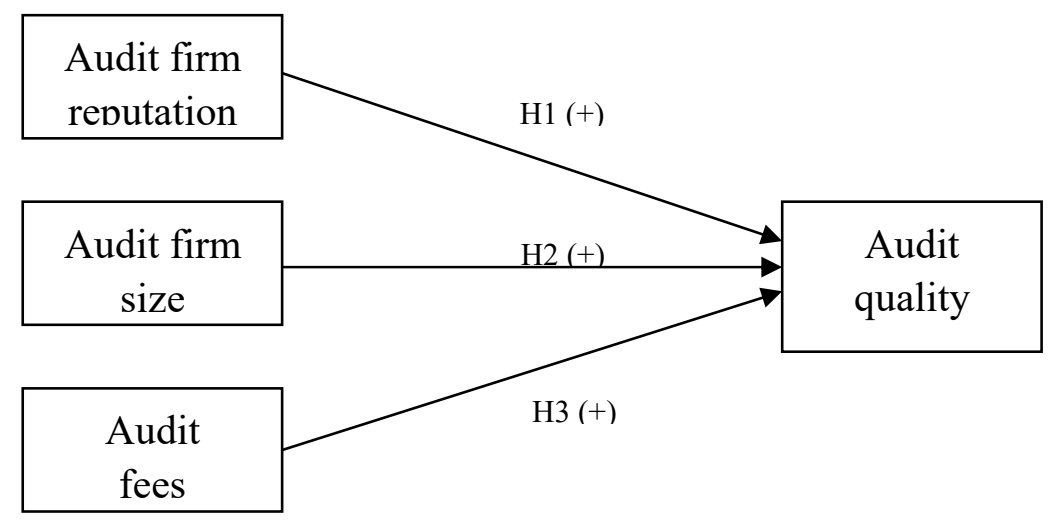

Figure 1. Hypothesized model of factors effecting audit quality

\section{Research method}

\subsection{Sample Selection}

We selected all publicly-listed companies in Hanoi, Ho Chi Minh Stock Exchange over the entire duration of the estimated time period (2006-2014) as initial samples. A company included in the sample needs to be satisfied the following four conditions: (1) the company remains listed during the period 2006 to 2014; (2) audit firms of the company are relatively stable over time; (3) a company that has either missing financial variables or insufficient data is eliminated; and (4) the company does not belong to financial institutions, banking, finance and investment firms, since their accounting and reporting environments differ from those in other industries. These conditions give a final sample of 192 firms.

\subsection{Regression model and measurement of variables}

The equation (3) is used to test hypotheses developed for this study.

$A Q=\beta_{0}+\beta_{1} A D F R e p+\beta_{2} A D F$ size $+\beta_{3} A D F e e+\beta_{4} C F O+\beta_{5} L E V+\beta_{6} R O A+\varepsilon$

In equation (3), dependent variable is audit quality $\left(A Q_{i t}\right)$ which is measured by discretionary accruals in equation (1). Independent variables included audit firm reputation (ADFRep), audit firm size (ADFsize) and audit fees (ADFee). The following is the measurements of these independent variables.

ADFRep $\quad 1$ if the firm is audited by a Big 4 auditor, 0 otherwise.

ADFsize Natural log of audit firm's total assets.

ADFee Natural log of total audit fees of the firm

We used cash flow from operations (CFO) as a control variable because CFO influences corporate management actions in managing earnings which are proxy of audit quality (Becker 
et al., 1998). Leverage (LEV) is included as firms with a higher likelihood of violating debt agreements are more likely to have an incentive to engage in earnings management so as to reduce audit quality (Ramadan, 2015; Sweeney, 1994). We also controlled for return on assets (ROA) as performance of the firm may affect the application of accruals to manage earnings (Kothari et al., 2005) which indicate low audit quality. The following is the measurements of these control variables.

CFO Operating cash flow divided by total assets at fiscal year end

LEV Ration of total debt to total assets

ROA Total income before extraordinary items divided by average total assets

\section{Results}

Table II presents a summary of descriptive statistics of the dependent and independent variables used in the study. The mean value for audit quality (AQ) is 0.06 with 27 percent of the sample are audited by Vietnamese Big 4 auditors. The positive values of the mean and median of audit quality (AQ) suggest that most of the companies manipulate earnings upward. The mean value for ADFee is 18.046, which is equivalent to 2,918 USD. The mean value of LEV is 1.26 which suggests that Vietnamese listed companies operate with high level of financial leverage.

Table II. Descriptive statistics

\begin{tabular}{lrrrrrrr}
\hline & \multicolumn{7}{c}{ ADF } \\
& AQ & ADFSize & Reputation & ADFee & CFO & LEV & ROA \\
\hline N & 192 & 192 & 192 & 192 & 192 & 192 & 192 \\
\cline { 2 - 8 } Valid Missing & 0 & 0 & 0 & 0 & 0 & 0 & 0 \\
\cline { 2 - 8 } Mean & 0.060 & 26.677 & 0.27 & 18.046 & 0.05 & 1.26 & 0.049 \\
\cline { 2 - 8 } Median & 0.063 & 27 & 0 & 18 & 0.04 & 0 & 0.039 \\
Std. Deviation & 0.228 & 1.562 & 0.446 & 0.704 & 0.132 & 5.384 & 0.084 \\
\cline { 2 - 8 } Minimum & -0.705 & 23 & 0 & 17 & -0.542 & 0 & -0.657 \\
Maximum & 0.909 & 30 & 1 & 19 & 0.755 & 70 & 0.293 \\
\hline
\end{tabular}


Table III. Model summary

\begin{tabular}{|r|r|r|r|r|}
\hline & & & & \\
Model & $\mathrm{R}$ & R Square & Adjusted R Square & $\begin{array}{r}\text { Std. Error of the } \\
\text { Estimate }\end{array}$ \\
\hline 1 &, $294^{\mathrm{a}}$ &, 087 &, 057 & 3,1210061063 \\
\hline
\end{tabular}

Predictors: (Constant), LEV, ADFee, CFO, ADFSize, ADFRep

Table III shows that the $\mathrm{R}^{2}$ of 8.7 percent of the variation of audit quality which is explained by the effects of the three firm characteristics. To investigate the existence of multicollinearity, the variance inflation factors (VIF) for each of the independent variables are calculated. As reported in column 8 of Table IV, VIFs for the explanatory variables are all below 5, suggesting that multicollinearity is not likely to be an influential factor driving the results.

Table IV. Multiple regression results

\section{Coefficients $^{\mathrm{a}}$}

\begin{tabular}{|c|c|c|c|c|c|c|c|}
\hline \multirow[b]{2}{*}{ Model } & \multicolumn{2}{|c|}{$\begin{array}{c}\text { Unstandardized } \\
\text { Coefficients }\end{array}$} & \multirow{2}{*}{$\begin{array}{c}\text { Standardized } \\
\text { Coefficients } \\
\text { Beta }\end{array}$} & \multirow[b]{2}{*}{$\mathbf{t}$} & \multirow[b]{2}{*}{ Sig. } & \multicolumn{2}{|c|}{$\begin{array}{c}\text { Collinearity } \\
\text { Statistics }\end{array}$} \\
\hline & B & $\begin{array}{l}\text { Std. } \\
\text { Error }\end{array}$ & & & & Tolerance & VIF \\
\hline (Constant) & -41.227 & 11.56 & & -3.565 & .000 & & \\
\hline ADFee & 1.629 & .577 & .356 & 2.823 & .005 & .309 & 3.233 \\
\hline ADFRep & -2.913 & 1.003 & -.403 & -2.90 & .004 & .256 & 3.912 \\
\hline ADFSize & .533 & .179 & .259 & 2.968 & .003 & .649 & 1.541 \\
\hline $\mathrm{CFO}$ & -.072 & .056 & -.090 & -1.281 & .202 & .992 & 1.008 \\
\hline LEV & -.016 & .043 & -.027 & -.380 & .705 & .973 & 1.028 \\
\hline
\end{tabular}

a. Dependent Variable: DA proxy for $A Q$ (Audit quality)

Table IV shows that the standardized coefficient of AudRep in the model is -0.403 and is significant at the 0.05 level. This result indicates a significant positive relationship between audit reputation and audit quality. Thus, the result supports H1. The standardized coefficients for ADFSize and AudFee in the model are negative 0.259 and 0.356 , respectively. They are all significant at the 0.05 level. The results suggest a significantly negative relationship between audit firm size and audit quality, and between audit fees and audit quality. The analysis, thus, does not support the hypothesis $\mathrm{H} 2$ and H3. Table V shows the results of hypotheses testing. 
Table 5. Results of hypotheses testing

\begin{tabular}{llcc}
\hline & & \multicolumn{2}{c}{ Result of the test } \\
\cline { 3 - 4 } No. & \multicolumn{1}{c}{ Hypothesis } & Hypothesis & Relation \\
\hline H1 & $\begin{array}{l}\text { Audit quality has a positive association with audit firm } \\
\text { reputation }\end{array}$ & Support & Positive \\
H2 & $\begin{array}{l}\text { Audit quality has a positive association with audit firm } \\
\text { size }\end{array}$ & Not & Negative \\
H3 & Audit quality has a positive association with audit fees & Support & \\
& & Support & Negative \\
\hline
\end{tabular}

\section{Discussion and conclusion}

\subsection{Discussion}

Prior studies on audit quality have focused on firms from developed countries (Beisland et al., 2015). Little is known about audit quality in emerging economies, such as Vietnam. This study is the first to investigate the impacts of audit firms' characteristics on audit quality of listed firms in Vietnam, using earnings management measurement as a proxy for audit quality.

Based on a sample of 192 firms from Hanoi and Ho Chi Minh Stock Exchange for fiscal years 2005 to 2014, the study finds that only audit firm reputation is positively associated with audit quality. The results of this study are broadly in line with prior studies (e.g. Becker et al., 1998; Francis and Wang, 2008; Krishnan, 2003). This study measured the audit firm reputation by Big 4 auditors versus non-Big 4 auditors. The results of this study indicate that companies which are audited by Big 4 auditors generally engage in less earnings management than firms audited by non-Big 4. It means that Big 4 auditors in Vietnam provide high audit quality than non-Big 4 auditors.

The higher audit quality of the Big 4 auditors in Vietnam may also be explained by the institutional context of Vietnam where there is a big gap in the quality-control systems that ensure the high quality of assurance services between the Big Four in Vietnam and Vietnam audit firms (Do, 2013). The Big four in Vietnam normally adapts the quality control system, such as audit guidelines, working papers and other technical resources, from their mother companies (Do, 2013). Meanwhile, most of Vietnam audit companies have a lack of financial resource to spend on training or hiring reputation auditors and do not have high technical competence compared to that of the Big four. All of these factors are big barriers for Vietnam audit firms in improving their assurance services.

The results indicate that audit firm size is significantly negatively related to audit quality. The results of this study are not consistent with prior studies (e.g. Rezaei and Shabani, 2014; Sundgren and Svanström, 2013) who argue that bigger audit firms often provide better assurance services. Except for the audit firms in the Big 4 group, the findings suggest that smaller audit firms provide better audit quality while bigger audit firms does not necessary 
result in better audit quality.

In Vietnam context, although larger audit firms have a better internal control system, however, larger audit firms in Vietnam normally have larger clients and gain more benefit to indulging clients more than smaller audit firms, which lead to the dependence of auditors on their clients. The appointment of audit firms of most listed companies in Vietnam heavily emphasis on the brand name, the prestige and the capacity to deliver an audit on time and less rely on the independence of auditors (International Finance Corporation, 2011). Especially, the shareholders' role and interfacing with the auditor is poor in Vietnam (International Finance Corporation, 2011, 2012). The board of directors normally appoint of the external auditor (International Finance Corporation, 2012), thus they may select large audit firms to send a signal of high audit quality to shareholders, on another hand, they may enter into collusion with these audit firms to protect their own interests.

The findings of this study also reveal that audit fees significantly negatively affect audit quality. The result of this study is not consistent with prior studies (e.g. Hoitash et al., 2007; Simunic, 1980; Sundgren and Svanström, 2013), who argued that low audit fees lead to the decreasing number of auditors and shorter time of auditing which results in lower audit quality. In contrast, the result of this study suggests that high audit fees can lead to an independence issue for auditors. When the auditor receives high audit fees from their clients, the auditors may allow the client to engage in opportunistic earnings management. Thus, the results of this study support Kinney and Libby (2002) who stated that "unexpected non-audit and audit fees may more accurately be likened to attempted bribes and will reduce the quality of reported earnings through the auditor's reduced willingness to resist client biases to manage earnings" (p.109). The results also suggest that high audit fees make them more economically dependent on their clients which can lead to the independent issues of auditors (Wooten, 2003).

\subsection{Implications}

This study has implications with respect to selecting audit firms in Vietnam. First, the finding highlights that, excepting for Big 4 audit firms, the audit quality of Vietnamese audit firms is still a big issue - larger audit firms tend to ignore more of their clients' manipulations of earnings and higher fees may reflect the collusion between audit firms and their clients. Thus, the decision of choosing big audit firms or whose having higher audit fees with the expectation of them providing good service of audit quality has to be considered carefully and base on many different assessments.

Second, the finding also indicates that the Big 4 auditors have higher audit quality than the non-Big 4, thus the non-Big 4 in Vietnam should invest more resources in training or hiring competent auditors and upgrade their technical competence. Vietnam Association of Certified Public Accounting should play more significant role in oversight the audit activities of both Vietnam audit firms and other foreign non-big 4 firms in Vietnam. Thus, these firms can improve their competencies to compete with the Big 4 auditors.

Third, shareholders of listed companies in Vietnam should understand and fully conduct their 
rights, such as appoint external auditors and oversight the independence of auditors to ensure the audit quality of external auditors. The conducting of shareholders right also prevent the board of directors from choosing larger audit firms, paying higher audit fees and also impairing auditor independence.

\subsection{Limitations and future research}

In Vietnam, data availability is limited, therefore, this research examined only the three factors, including: (1) audit firm size, (2) audit firm reputation, and (3) audit fees. Future research needs to include other factors of audit firms, such as auditor's competence, audit effort, audit methodology and audit support system which may also affect audit quality.

In addition, this study is based on data from a short period of 8 years to estimate discretionary accruals which is the proxy for audit quality in 2014. However, financial reporting quality may also depend on other factors than solely accruals. For instance, shifts within the income statement between operating profit and non-operating profit, presentation and classification of assets and liabilities, accounting of business combinations, and certain notes are also important proxies to measure audit quality. That is the limitation of discretionary accruals for being used to measure audit quality in this study. Future research can use other input-base factors to measure the audit quality and determine their effects on audit quality.

\section{References}

Almomani, M. A. (2015). The impact of audit quality features on enhancing earnings quality: The evidence of listed manufacturing firms at amman stock exchange. Asian Journal of Finance \& Accounting, 7(2), 255-280. https://doi.org/10.5296/ajfa.v7i2.8539

Alyousef, H. Y., \& Almutairi, A. R. (2010). An empirical investigation of accounting restatements by public companies: Evidence from kuwait. International Review of Business Research Papers, 6(1), 513-535.

Aronmwan, E. J., Ashafoke, T. O., \& Mgbame, C. O. (2013). Audit firm reputation and audit quality. European Journal of Business and Management, 5(7), 66-75.

Augustine, O. E., Mgbame, C., Efayena, O., \& Edegware, J. (2014). Audit firm characteristics and auditing quality: The nigerian experience. Research Journal of Finance and Accounting, 5(6), 23-34.

Beatty, R. P. (1989). Auditor reputation and the pricing of initial public offerings. The Accounting Review, 64(4), 693-709.

Becker, C. L., DeFond, M. L., Jiambalvo, J., \& Subramanyam, K. (1998). The effect of audit quality on earnings management. Contemporary Accounting Research, 15(1), 1-24. https://doi.org/10.1111/j.1911-3846.1998.tb00547.x

Beisland, L. A., Mersland, R., \& Strøm, R. Ø. (2015). Audit quality and corporate governance: Evidence from the microfinance industry. International Journal of Auditing, 19(3), 218-237. https://doi.org/10.1111/ijau.12041 
Bigus, J. (2015). Auditor reputation under different negligence regimes. Abacus, 51(3), 356-378. https://doi.org/10.1111/abac.12051

Boulila Taktak, N., \& Mbarki, I. (2014). Board characteristics, external auditing quality and earnings management: Evidence from the tunisian banks. Journal of Accounting in Emerging Economies, 4(1), 79-96. https://doi.org/10.1108/JAEE-10-2011-0046

Bùi Văn Mai. (2014). An overview the current situation of vietnam independent auditing. available at: http://www.vacpa.org.vn/Page/Detail.aspx?newid=4735, (accessed 15 September 2015).

Carcello, J. V., Hermanson, D. R., Neal, T. L., \& Riley, R. A. (2002). Board characteristics and audit fees. Contemporary Accounting Research, 19(3), 365-384. https://doi.org/10.1506/CHWK-GMQ0-MLKE-K03V

Carey, P. J. (2008). The benefits of services provided by external accountants to small and medium sized enterprises. (Doctor of Philosophy), University of New South Wales, New South Wales.

Casterella, J. R., Jensen, K. L., \& Knechel, W. R. (2009). Is self-regulated peer review effective at signaling audit quality?. The Accounting Review, 84(3), 713-735. https://doi.org/10.2308/accr.2009.84.3.713

Choi, J.-H., Kim, C., Kim, J.-B., \& Zang, Y. (2010). Audit office size, audit quality, and audit pricing. Auditing: A Journal of Practice \& Theory, 29(1), 73-97. https://doi.org/10.2308/aud.2010.29.1.73

DeAngelo, L. E. (1981). Auditor size and audit quality. Journal of accounting and economics, 3(3), 183-199. https://doi.org/10.1016/0165-4101(81)90002-1

DeFond, M., \& Zhang, J. (2014). A review of archival auditing research. Journal of Accounting and Economics, 58(2), 275-326. https://doi.org/10.1016/j.jacceco.2014.09.002

DeFond, M. L. (2010). Earnings quality research: Advances, challenges and future research. Journal of Accounting and Economics, 50(2), 402-409. https://doi.org/10.1016/j.jacceco.2010.10.004

Desai, V., Xu, B., zeng, t., \& Sarens, G. (2016). Local accounting firms' pricing responses to entry of the big four accounting firms into china. Journal of Accounting in Emerging Economies, 6(1). https://doi.org/10.1108/JAEE-06-2013-0030

Do, H. (2013). Audit market: Majesty right of the big four. available at: https://translate.google.com/translate?sl=vi\&tl=en\&js=y\&prev= t\&hl=vi\&ie=UTF-8\&u=http $\% 3 \mathrm{~A} \% 2 \mathrm{~F} \% 2 \mathrm{Fvneconomy.vn} \% 2 \mathrm{Fdoanh}$-nhan $\% 2 \mathrm{Fthi}$-truong-kiem-toan-quyen-uy-cua-big-fo ur-20131104111718710.htm\&edit-text $=$, (accessed 23 December 2016).

Do, H. H., \& Ngo, S. T. (2015). The factors affect the quality of financial statements audit in vietnam businesses. Asian Social Science, 11(27), 172-181.

Ettredge, M., Fuerherm, E. E., \& Li, C. (2014). Fee pressure and audit quality. Accounting, 
Organizations and Society, 39(4), 247-263. https://doi.org/10.1016/j.aos.2014.04.002

Francis, J. R. (2011). A framework for understanding and researching audit quality. Auditing: A journal of practice \& theory, 30(2), 125-152. https://doi.org/10.2308/ajpt-50006

Francis, J. R., Maydew, E. L., \& Sparks, H. C. (1999). The role of big 6 auditors in the credible reporting of accruals. Auditing: A Journal of Practice \& Theory, 18(2), 17-34. https://doi.org/10.2308/aud.1999.18.2.17

Francis, J. R., \& Wang, D. (2008). The joint effect of investor protection and big 4 audits on earnings quality around the world. Contemporary Accounting Research, 25(1), 91-157. https://doi.org/10.1506/car.25.1.6

Francis, J. R., \& Yu, M. D. (2009). Big 4 office size and audit quality. The Accounting review, 84(5), 1521-1552. https://doi.org/10.2308/accr.2009.84.5.1521

Grenier, J. H., Peecher, M. E., \& Piercey, M. D. (2007). Judging auditor negligence: De-biasing interventions, outcome bias, and reverse outcome bias. Working Paper, University of Illinois, 19 September. https://doi.org/10.2139/ssrn.1015523

Ha, P. V. (2014). The effects of corporate governance mechanisms to the level of disclosures in annual reports. Journal of Economic Studies, 2(4), 115-127.

Healy, P. M., \& Wahlen, J. M. (1999). A review of the earnings management literature and its implications for standard setting. Accounting horizons, 13(4), 365-383. https://doi.org/10.2308/acch.1999.13.4.365

Hoitash, R., Markelevich, A., \& Barragato, C. A. (2007). Auditor fees and audit quality. Managerial Auditing Journal, 22(8), 761-786. https://doi.org/10.1108/02686900710819634

International Finance Corporation. (2011). Vietnam corporate governance scorecard (Second ed.). Pennsylvania: International Finance Corporation.

International Finance Corporation. (2012). Vietnam corporate governance scorecard (Third ed.). Pennsylvania: International Finance Corporation.

Jones, J. J. (1991). Earnings management during import relief investigations. Journal of accounting research, 29(2), 193-228. https://doi.org/10.2307/2491047

Kinney, W. R., \& Libby, R. (2002). Discussion of the relation between auditors' fees for nonaudit services and earnings management. The Accounting Review, 77, 107-114. https://doi.org/10.2308/accr.2002.77.s-1.107

Klein, B., \& Leffler, K. B. (1981). The role of market forces in assuring contractual performance. The Journal of Political Economy, 89(4), 615-641. https://doi.org/10.1086/260996

Kothari, S. P., Leone, A. J., \& Wasley, C. E. (2005). Performance matched discretionary accrual measures. Journal of accounting and economics, 39(1), 163-197. https://doi.org/10.1016/j.jacceco.2004.11.002 
Krishnan, G. V. (2003). Audit quality and the pricing of discretionary accruals. Auditing: A Journal of Practice \& Theory, 22(1), 109-126. https://doi.org/10.2308/aud.2003.22.1.109

Lawrence, A., Minutti-Meza, M., \& Zhang, P. (2010). Can big 4 versus non-big 4 differences in audit-quality proxies be attributed to client characteristics?. Accounting Review, 86(1), 259-288. https://doi.org/10.2308/accr.00000009

Lawrence, A., Minutti-Meza, M., \& Zhang, P. (2011). Can big 4 versus non-big 4 differences in audit-quality proxies be attributed to client characteristics?. The Accounting Review, 86(1), 259-286. https://doi.org/10.2308/accr.00000009

Lennox, C. (1999). Are large auditors more accurate than small auditors?. Accounting and business research, 29(3), 217-227. https://doi.org/10.1080/00014788.1999.9729582

Mamun, S. A. A., \& Badir, Y. (2014). Convergence of corporate governance in malaysia and thailand. Journal of Accounting in Emerging Economies, 4(1), 2-21. https://doi.org/10.1108/JAEE-08-2011-0027

Oxford Analytica. (2008). Corporate governance in vietnam weakens. available at: http://www.forbes.com/2008/09/10/vietnam-inflation-economy-cx_0911oxford.html, (accessed 26 October 2015).

Palmrose, Z.-V., \& Scholz, S. (2000). Restated financial statements and auditor litigation. Working paper, University of Southern California, October. https://doi.org/10.2139/ssrn.248455

Palmrose, Z. V. (1988). An analysis of auditor litigation and audit service quality. The accounting review, 63(1), 55-73.

Pham, H., Amaria, P., Bui, T., \& Tran, S. (2014). A study of audit quality in vietnam. International Journal of Business, Accounting, \& Finance, 8(2), 73-100.

Pham, N. T., \& Hoang, T. T. H. (2015). The effects of firm characteristics on the level of financial disclosures of listed companies on ho chi minh stock exchange. Economic Development Review, 26(4), 87-103.

Quang, T. (2013). Vietnam: An emerging economy at a crossroads. Working paper, Maastricht school of management, 2 May 2015.

Raghunandan, K., Read, W. J., \& Whisenant, J. S. (2003). Initial evidence on the association between nonaudit fees and restated financial statements. Accounting Horizons, 17(3), 223-234. https://doi.org/10.2308/acch.2003.17.3.223

Ramadan, I. Z. (2015). Does ownership structure affect jordanian companies' tendency to practice earnings management?. Asian Journal of Finance \& Accounting, 7(2), 281-291. https://doi.org/10.5296/ajfa.v7i2.8537

Rezaei, F., \& Shabani, S. (2014). The effect of audit firm size and age on the quality of audit work. European Online Journal of Natural and Social Sciences, 3(1), pp. 56-64. 


\section{Macrothink}

Asian Journal of Finance \& Accounting

ISSN 1946-052X

2017, Vol. 9, No. 1

Ronen, J., \& Yaari, V. (2008). Earnings management: Emerging insights in theory, practice, and research, Springer, London.

Schipper, K. (1989). Commentary on earnings management. Accounting horizons, 3(4), 91-102.

Simunic, D. A. (1980). The pricing of audit services: Theory and evidence. Journal of accounting research, 18(1), 161-190. https://doi.org/10.2307/2490397

Sucher, P., Moizer, P., \& Zarova, M. (1999). The images of the big six audit firms in the czech republic. The European Accounting Review, 8(3), 499-521. https://doi.org/10.1080/096381899335916

Sundgren, S., \& Svanström, T. (2013). Audit office size, audit quality and audit pricing: Evidence from small-and medium-sized enterprises. Accounting and Business Research, 43(1), 31-55. https://doi.org/10.1080/00014788.2012.691710

Sweeney, A. P. (1994). Debt-covenant violations and managers' accounting responses. Journal of accounting and Economics, 17(3), 281-308. https://doi.org/10.1016/0165-4101(94)90030-2

Teoh, S. H., \& Wong, T. (1993). Perceived auditor quality and the earnings response coefficient. The Accounting Review, 68(2), 346-366.

Tritscher, J. (2013), Audit quality: Association between published reporting errors and audit firm characteristics, Springer Gabler, Wiesbaden.

Vietnam Investment Review. (2015). Corporate governance in vietnam. available at: https://translate.google.com/translate? sl=vi\&tl=en\&js=y\&prev= t\&hl=en\&ie $=\mathrm{UTF}-8 \& \mathrm{u}=\mathrm{htt}$ $\mathrm{p} \% 3 \mathrm{~A} \% 2 \mathrm{~F} \% 2 \mathrm{Ftinnhanhchungkhoan.vn} \% 2 \mathrm{Fchung}$-khoan\%2Fquan-tri-cong-ty-o-viet-nam-de -ra-cho-co-115062.html\&edit-text=, (accessed 24 December 2015).

Charter issue forms to apply for listed companies, Decision No. 07/2002/QD-OG C.F.R. (2002).

Vu, Q. (2010). Auditing sector: Both quality and quantity shortess . available at: http://www.vacpa.org.vn/Page/Detail.aspx?newid=4259, (accessed 15 September 2015).

Williams, D. D. (1988). The potential determinants of auditor change. Journal of Business $\begin{array}{llll}\text { Finance accounting } \quad \text { and } & \text { 243-261. }\end{array}$ https://doi.org/10.1111/j.1468-5957.1988.tb00133.x

Wooten, T. C. (2003). Research about audit quality. The CPA Journal, 73(1), 48-51. 